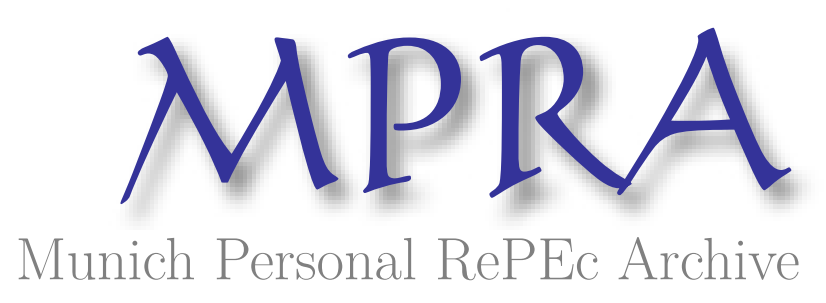

\title{
The Short-Run Impacts of Connecticut's Paid Sick Leave Legislation
}

\author{
Ahn, Thomas and Yelowitz, Aaron \\ University of Kentucky, University of Kentucky
}

August 2014

Online at https://mpra.ub.uni-muenchen.de/57885/

MPRA Paper No. 57885, posted 15 Aug 2014 10:57 UTC 
The Short-Run Impacts of Connecticut's Paid Sick Leave Legislation

Thomas Ahn ${ }^{*}$

Aaron Yelowitz

Abstract: In 2012, Connecticut became the first state to enact paid sick leave legislation. Using a difference-in-differences framework, we find the law had modest but negative effects on the labor market, particularly on the likelihood of working in the past week.

JEL Classification: J33, J38, H75, I18, I12

Keywords: Paid sick leave, Mandated benefits, Difference-in-differences, Fringe benefits, Employment

* Ahn (corresponding author) Contact Information:

E-mail - thomas.ahn@uky.edu

Telephone - 859-257-5975

Fax - 859-323-1920 
Introduction

Roughly 80 percent of low-wage workers in the U.S. do not have access to paid sick leave.

Commentators have noted that the U.S. lags behind other countries by failing to mandate employers offer paid sick leave (Heymann et al. 2007). This proposition has been gaining popular and legislative support across many U.S. cities and states. President Obama has called for a federal law to guarantee workers paid sick leave to recover from illness or care for sick family members (Obama 2014).

At the same time, there are fears that mandating paid sick leave will lead to negative labor market consequences. The arguments are similar to those advanced against minimum wage increases or mandated employer-provided health insurance: more workers will enter the low-wage labor market and businesses will reduce hiring, which will hurt workers who most desperately need jobs (Summers 1989; Kolstad \& Kowalski 2014). On the other hand, it is possible that this policy will not have much impact. Most paid sick leave laws equate to very slight pay increases. Compared to other reforms, the benefits to workers and costs to businesses are minor. Whether there is an observable impact is an empirical question, where greater care must be taken to ensure that the empirical framework does not suffer from bias as any impact generated is expected to be small.

We use the American Community Survey (ACS), a difference-in-differences approach, and the paid sick leave law enacted in Connecticut in 2012 to estimate the initial impacts of the mandate. This approach is attractive for three reasons. First, statewide implementation avoids concerns about overlapping labor markets, an issue present with citywide implementation (Ahn 2011). Second, Connecticut is surrounded by similar states that serve as a control. Third, several nearby states will soon introduce paid sick leave, which dampens mobility responses across state borders.

\section{$\underline{\text { Data }}$}

We use one-year samples of the 2009-2012 ACS Public Use Microdata Sample (PUMS). The number of records contained in a one-year PUMS file is about one percent of the total in the nation. ${ }^{1}$ Unlike most surveys, respondents are required to participate in the ACS. ${ }^{2}$ To create the sample, we examine Connecticut and the five other states that comprise the New England region (Massachusetts, New Hampshire, Vermont, Rhode Island, and Maine).

\footnotetext{
${ }^{1}$ http://www.census.gov/acs/www/data documentation/public use microdata sample/

2 http://www.census.gov/acs/www/Downloads/language brochures/ACSQandA ENG10.pdf.
} 
The ACS asks labor force information on individuals aged 16 and older; we focus on individuals aged 16 to 64 , excluding individuals who have imputed values on key demographic variables. We also exclude an individual from a particular regression if the pertinent response was imputed. ${ }^{3}$ We focus on three contemporaneous measures of work activity: work in the previous week, unemployment and labor force participation. $^{4}$

Table 1 presents summary statistics. In the full sample, there are more than 347,000 individuals. The typical respondent worked more than 1,400 hours per year. More than three-quarters of the sample was in the labor force, and of those, 9 percent was unemployed. Approximately 37 percent of the sample has a high school diploma or less, more than 80 percent is white, and 7 percent is legal noncitizens. Labor market outcomes gradually improved over this period, as the economy was emerging from the Great Recession. The final two columns compare Connecticut to other New England states. Although many labor market variables are similar, annual wage income is higher in Connecticut. It also has a larger fraction minority and non-citizens. Among those who are working (or had worked in the past 5 years), nearly 30 percent are classified as service workers, the occupation targeted by the law.

\section{Description of the Connecticut Paid Sick Leave Law}

Connecticut General Statute 31-57r mandates that large firms (50 or more employees) must offer paid sick leave to service workers beginning January 1, 2012. A worker accrues one hour of sick leave for every 40 hours worked, which equates to a 2.5 percent pay increase at most (if all sick leave hours are used). Workers cannot earn (or use) more than 40 hours of sick leave and are allowed to carry over a maximum of 40 hours from year to year. In 2012, no other New England state had a similar law in place.

Table 2 shows - using County Business Patterns data for Connecticut in 2012 - the fraction of workers in each industry employed at large firms. The mandate would be expected to have large impacts on the "Educational Services," “Management of Companies and Enterprises," "Health Care and Social Assistance," "Administrative and Support," "Transportation and Warehousing," and "Information" sectors. Although "Manufacturing" should have many affected workers, this industry was exempt from the mandate.

\footnotetext{
${ }^{3}$ This follows recommendations of Bollinger and Hirsch (2006).

${ }^{4}$ The ACS contains annual measures of work, but we cannot use them in the analysis because the answers mostly pertain to the period before the sick leave law.
} 


\section{Theory Model}

Below is a simple theory model that sketches out some predictions to test for in the empirical section:

Assume there are two types of workers: young $(y)$ and old (o). Both have a uniform distribution of ability $\delta \in[0,1]$. There are $\bar{N}_{y}$ and $\bar{N}_{o}$ potential young and old workers, respectively. There is one type of firm in the economy that can choose to search for either young or old workers. The firms create vacancies until the expected zero profit condition binds.

Assume that old workers must be out of work sick that is equivalent to productivity $s_{o}$. Equivalently, young workers must be out of work sick that is equivalent to productivity $s_{y}$. Assume for simplicity that $s_{y}=0$.

Utility of old and young workers are defined thusly:

$$
\begin{gathered}
U_{o}=P_{o}\left(\text { Wage }_{o}+\alpha s_{o}\right)-K \\
U_{y}=P_{y}\left(\text { Wage }_{y}\right)-K
\end{gathered}
$$

Where $\alpha$ is a measure of utility gained from being home to nurse a potential illness (compared to having to come to work), and $K$ is a search cost that must be paid to seek to match with a vacancy. Assume again, for simplicity, that $K=1$. The probability of finding a vacancy for old and young workers is defined by:

$$
\begin{aligned}
& P_{o}=\frac{x_{o}}{N_{o}} \\
& P_{y}=\frac{x_{y}}{N_{y}}
\end{aligned}
$$

The number of matches $x_{k}$ where $k=y$ or $o$, is a Cobb-Douglas on the interior:

$$
x_{k}=\min \left\{\gamma J_{k}^{\theta} N_{k}^{\theta}, J_{k}, N_{k}\right\}
$$

The $\gamma$ is a normalizing constant, and $\theta \in(0,1)$. For simplicity, we assume $\theta=\frac{1}{2}$, which is consistent with a CRS matching function where the number of vacancies $\left(U_{k}\right)$ and number of searchers $\left(N_{k}\right)$ equally contribute to the probability of matching with each other. 
Wage is defined by a Rubenstein bargaining game with firms, such that for the worker takes the share of the productivity generated. The bargaining power of the worker is $\beta, \beta \in(0,1)$. Therefore, the wage for old and young workers, respectively, is:

$$
\begin{gathered}
\text { Wage }_{o}=\beta\left(\delta_{i}-s_{o}\right) \\
\text { Wage }_{y}=\beta\left(\delta_{i}\right)
\end{gathered}
$$

Clearly, for two workers with identical abilities, under the model with no mandated paid-sick-leave, younger workers are paid a higher wage than older workers, since they are more productive, due to less days out sick.

Then it is trivial to show that the marginal old (young) worker to search is:

$$
\begin{gathered}
\delta_{o}^{*}=\left[\frac{1}{P_{o}}+(\beta-\alpha) s_{o}\right] \frac{1}{\beta} \\
\delta_{y}^{*}=\left[\frac{1}{P_{y}}\right] \frac{1}{\beta}
\end{gathered}
$$

That is, old and young workers find it worthwhile to search for a job as long as their ability is above the cut off ability value defined above. Note that for similar values of probability of matching from the worker side, $\delta_{o}^{*}<\delta_{y}^{*}$, since we expect $(\beta-\alpha)>0$ (as is the nature of involuntary sick days). Since ability is distributed uniform, the number of old and young searchers is defined by:

$$
\begin{aligned}
& \left(1-\delta_{o}^{*}\right) \cdot \bar{N}_{o}=N_{o} \\
& \left(1-\delta_{y}^{*}\right) \cdot \bar{N}_{y}=N_{y}
\end{aligned}
$$

Firms search for old and young workers according to the following expected zero-profit condition:

$$
\begin{gathered}
q_{o}(1-\beta)\left(E(\delta \mid o)-s_{o}\right)-C=0 \\
q_{y}(1-\beta) E(\delta \mid y)-C=0
\end{gathered}
$$

Where $q_{k}$ is the probability of the firm successfully matching with a worker in $k=y$ or $o$. Note that because of the uniform distribution assumption, we can plug in for $E(\delta \mid o)=\frac{1-\delta_{0}^{*}}{2}$ and $E(\delta \mid y)=\frac{1-\delta_{y}^{*}}{2}$. 
Solving for the fraction of searching workers over the number of vacancies: $\frac{N_{k}}{J_{k}}$ and simplifying, we find that:

$$
\frac{N_{k}}{J_{k}}=\frac{\sigma^{2} \pm\left(\sigma^{4}-4 \sigma^{2} \omega-2 \omega\right)^{1 / 2}}{2}
$$

Where $\sigma=\left(\beta-(3 \beta-\alpha) s_{k}\right) \gamma$ and $\omega=\frac{2 \beta C}{(1-\beta)}$. There are two potential solutions, where the ratio in question can increase or decrease depending on whether we use

$$
\frac{N_{k}}{J_{k}}=\frac{\sigma^{2}-\left(\sigma^{4}-4 \sigma^{2} \omega-2 \omega\right)^{1 / 2}}{2}
$$

Or

$$
\frac{N_{k}}{J_{k}}=\frac{\sigma^{2}+\left(\sigma^{4}-4 \sigma^{2} \omega-2 \omega\right)^{1 / 2}}{2}
$$

The easiest way to see this is to note that as you increase the number of sick leaves you must take, your ability draw must also increase to make it worth your while to search for a position. Therefore, while the firm loses productivity from a sicker worker because he/she is absent more often, he/she is also more productive from the start (or in expectation, any worker will be more productive).

Therefore, paradoxically, the sicker worker in expectation will be more productive, and in some cases, will face higher or lower probability of unemployment, depending on the equilibrium, which is determined initially by the ratio of searching workers to vacancies.

Now, if a paid-sick-leave mandate is introduced, the worker and firm decisions change in the following manner:

$$
\begin{gathered}
U_{o}=P_{o}\left(\text { Wage }_{o}+\alpha s_{o}\right)-K \\
U_{y}=P_{y}\left(\text { Wage }_{y}+\alpha_{m} s_{m}\right)-K
\end{gathered}
$$

Here, $s_{m}$ is the mandated amount of paid-sick-leave. For young workers, $\alpha_{m}$ represents the value of "forced" sick days. They do not need to stay home desperately to nurse an illness, but they probably do 
get some amount of enjoyment out of it. Importantly, we assume that $\alpha_{m}$ is quite small, certainly smaller than $\beta$ : the point being that if they would trade in the paid-sick-leave for extra pay if they could. We assume that $s_{m}<s_{o}$. Note that the older worker utility function is identical. However, younger worker utility changes, since the worker may as well take the "free" vacation days offered.

The wages change in the following manner:

$$
\begin{gathered}
\text { Wage }_{o}=\beta\left(\delta_{i}-s_{o}\right)+\beta s_{m} \\
\text { Wage }_{y}=\beta\left(\delta_{i}-s_{m}\right)+\beta s_{m}=\beta \delta_{i}
\end{gathered}
$$

Note that the last term is the paid-sick-leave that is "returned" to the worker. Because our model is short-run, we assume sticky prices (wages), and firms cannot adjust the productivity measure to account for the paid-sick-leave.

Then, proceeding as before, we find:

$$
\begin{gathered}
\delta_{o}^{*}=\left[\frac{1}{P_{o}}+(\beta-\alpha) s_{o}\right] \frac{1}{\beta}-s_{m} \\
\delta_{y}^{*}=\left[\frac{1}{P_{y}}-\alpha_{m} s_{m}\right] \frac{1}{\beta}
\end{gathered}
$$

And the firm problem changes to:

$$
\begin{aligned}
& q_{o}\left[(1-\beta)\left(E(\delta \mid o)-s_{o}\right)-\beta s_{m}\right]-C=0 \\
& q_{y}\left[(1-\beta)\left(E(\delta \mid y)-s_{m}\right)-\beta s_{m}\right]-C=0
\end{aligned}
$$

We do not solve for the complete model here, but two points demonstrate the insight from our empirical section. First, unsurprisingly, because of the $-s_{m}$ term, $\delta_{o}^{*}$ must decline, compared to the no mandate regime. This means that more older workers are now searching (we are hand-waving a bit, since $P_{o}$ must also adjust). Younger workers increase search in the market as well, but the amount of change depends critically on $\alpha_{m}$. If this is very small, as we assume above, the change in the number of young workers is most likely very small, compared to the regime with no mandate. 
From the firm side, we see that recruitment for both young and old workers is dampened due to the extra burden of the paid-sick-leave: $-\beta s_{m}$. However, older workers are hit particularly hard here, because the $E(\delta \mid o)$ term is expected to decline precipitously. This is because a greater number of older workers who are less productive enter the market, driving down the expected random productivity draw from older workers. Then, to make up for this, $q_{o}$ must increase substantially. The only way this can be accomplished is for firms to severely pull back on the number of vacancies for older workers: $J_{o}$.

We predict that the labor force participation increase for young workers will be zero to a very small positive number. Employment change for young workers is also predicted to be a small negative number. Firms face higher cost, but increased LFPR of young workers will result in a higher probability of match from the firm side.

A paid-sick-leave mandate is expected to result in more older workers searching and higher unemployment for older workers. Note here that we do not allow firms to selectively choose higher ability older workers. If this type of selection is allowed, the impact for poor older workers would be even more severe.

\section{Empirical Analysis}

We rely on a "difference-in-differences" estimator:

$$
\text { OUTCOME }_{i s t}=\beta_{0}+\beta_{1} \text { POST }_{i t} \cdot \text { TREAT }_{i s}+\beta_{2} \text { POST }_{i t}+\beta_{3} T R E A T_{i s}+\beta_{4} X_{i}+\varepsilon_{i s t}
$$

where $O U T C O M E_{\text {ist }}$ is one of the contemporaneous labor market outcomes for individual $i$ in state $s$ in year $t, P O S T_{i t} \cdot T R E A T_{i s}$ is the interaction term that proxies for Connecticut's paid sick leave mandate, and $X_{i}$ is a set of characteristics that vary at the individual level. In various specifications we include dummy variables for $P_{\text {OST }}$ (or a set of year dummies), TREAT year trends. All specifications are estimated as linear models with weights, and standard errors are corrected for with non-nested two-way clustering at the state and year levels (Cameron, Gelbach, \& Miller, 2011).

The results in Table 3 show that the sick leave law had modest, but negative economic consequences. While this is unsurprising given the actual magnitude of the policy, our prior was that there would be no 
observable impact. However, the negative employment effect is clear across multiple specifications. ${ }^{5}$ The effect on labor force participation (LFPR) is small; LFPR increases by 0.3 percent. It is imprecisely estimated and, at most, suggestive of marginal workers being induced to enter the labor force. As a result of increased competition and decreased labor demand, the fraction of unemployed workers increases by 0.9 percentage points. Because firms respond by reducing the number of vacancies, deadweight loss is positive. The likelihood of working decreases by a similar amount.

At the bottom of Table 3, we separate the results by age, for several reasons. First, education may be incomplete for young workers. Second, sick leave is more valuable to those in poor health or those who have sick children, and older age proxies for this. Results suggest that older workers have a higher valuation of sick leave, and firms perceive older workers as more costly.

\section{Conclusion}

We analyzed the short-run impacts of Connecticut's sick leave law and found a small decrease in employment concentrated on older workers. Although there are real labor market impacts, the magnitudes seem rather small to justify the level of political and popular interest in the policy.

While our estimates capture the short-run impact of the law, they do not offer insight into long-run consequences. For instance, firms near state borders may relocate or adjust employee numbers/work hours. Firms in affected industries may also shift costs back to workers (Summers 1989; Gruber 1994). Our future work will examine these outcomes when data becomes available. The key market failure motivating paid sick leave laws is mitigating the spread of infectious disease. Given the modest labor market cost, future studies should also examine whether such benefits have appeared.

\footnotetext{
${ }^{5}$ If we include state and year fixed effects, state-year trends, individual demographic characteristics, and the state minimum wage, results become statistically insignificant. See appendix Table 1.
} 


\section{$\underline{\text { References }}$}

Ahn T. (2011) "Distributional Impacts of a Local Living Wage Increase with Ability Sorting" Economics Letters, 112(3): 283-286.

Bollinger C. R. \& B. T. Hirsch (2006) "Match Bias from Earnings Imputation in the Current Population Survey: The Case of Imperfect Matching," Journal of Labor Economics, 24(3): 483-520.

Cameron, A. C., Gelbach, J. B. \& D. L. Miller (2011) “Robust Inference With Multiway Clustering," Journal of Business \& Economic Statistics, 29(2): 238-249.

Gruber, J. (1994) "The Incidence of Mandated Maternity Benefits," American Economic Review, 84(3): 622-641.

Heymann J., Earle A., \& J. Hayes (2007) “The Work, Family and Equity Index: How Does the United States Measure Up?" Institute for Health \& Social Policy.

Kowloski, A. and J. Kolstad (2014) "Mandate-Based Health Reform and the Labor Market: Evidence from the Massachusetts Reform," NBER Working Paper 17933.

Obama, Barack (2014) State of the Union Address. http://www.washingtonpost.com/politics/full-textof-obamas-2014-state-of-the-union-address/2014/01/28/e0c93358-887f-11e3-a5bd-

844629433ba3 story.html (accessed 8/6/2014)

Summers, L. (1989) “Some Simple Economics of Mandated Benefits," American Economic Review, 79(3): 177-184. 


\begin{tabular}{|c|c|c|c|c|c|c|c|}
\hline \multicolumn{8}{|c|}{ Table 1: Summary Statistics } \\
\hline & All & 2009 & 2010 & 2011 & 2012 & $\mathrm{CT}$ & $\begin{array}{l}\text { Other } \\
\text { states }\end{array}$ \\
\hline In labor force & 0.789 & 0.794 & 0.787 & 0.786 & 0.787 & 0.794 & 0.787 \\
\hline Worked & 0.710 & 0.718 & 0.704 & 0.708 & 0.713 & 0.712 & 0.710 \\
\hline Unemployed & 0.090 & 0.087 & 0.097 & 0.090 & 0.086 & 0.098 & 0.087 \\
\hline $\begin{array}{l}\text { Hours in last } 12 \\
\text { months }\end{array}$ & $\begin{array}{c}1,422 \\
(1,020)\end{array}$ & $\begin{array}{c}1,453 \\
(1,007) \\
\end{array}$ & $\begin{array}{c}1,403 \\
(1,019) \\
\end{array}$ & $\begin{array}{c}1,412 \\
(1,028) \\
\end{array}$ & $\begin{array}{c}1,421 \\
(1,026) \\
\end{array}$ & $\begin{array}{c}1,427 \\
(1,027)\end{array}$ & $\begin{array}{c}1421 \\
(1,018)\end{array}$ \\
\hline $\begin{array}{l}\text { Worked in last } \\
12 \text { months }\end{array}$ & 0.803 & 0.820 & 0.799 & 0.796 & 0.799 & 0.800 & 0.804 \\
\hline $\begin{array}{l}\text { Wages in last } 12 \\
\text { months }\end{array}$ & $\begin{array}{c}37,029 \\
(57,690) \\
\end{array}$ & $\begin{array}{c}38,753 \\
(60,335) \\
\end{array}$ & $\begin{array}{c}36,806 \\
(57,217) \\
\end{array}$ & $\begin{array}{c}35,778 \\
(54,689) \\
\end{array}$ & $\begin{array}{c}36,740 \\
(58,276) \\
\end{array}$ & $\begin{array}{c}41,482 \\
(70,938) \\
\end{array}$ & $\begin{array}{r}35,609 \\
(52,694) \\
\end{array}$ \\
\hline $\begin{array}{l}\text { State minimum } \\
\text { wage }\end{array}$ & $\begin{array}{c}8.17 \\
(0.39) \\
\end{array}$ & $\begin{array}{c}8.37 \\
(0.34) \\
\end{array}$ & $\begin{array}{c}8.32 \\
(0.35) \\
\end{array}$ & $\begin{array}{c}8.07 \\
(0.34) \\
\end{array}$ & $\begin{array}{c}7.92 \\
(0.35) \\
\end{array}$ & $\begin{array}{c}8.48 \\
(0.16) \\
\end{array}$ & $\begin{array}{c}8.07 \\
(0.39) \\
\end{array}$ \\
\hline $\begin{array}{l}\text { Paid sick leave } \\
\text { mandate? }\end{array}$ & 0.060 & 0 & 0 & 0 & 0.241 & 0.247 & 0 \\
\hline Service worker & 0.291 & 0.278 & 0.297 & 0.294 & 0.296 & 0.29 & 0.292 \\
\hline Age & $\begin{array}{c}40.3 \\
(14.0) \\
\end{array}$ & $\begin{array}{c}40.1 \\
(13.8) \\
\end{array}$ & $\begin{array}{c}40.3 \\
(14.0) \\
\end{array}$ & $\begin{array}{c}40.5 \\
(14.1) \\
\end{array}$ & $\begin{array}{c}40.4 \\
(14.1)\end{array}$ & $\begin{array}{c}40.5 \\
(13.9) \\
\end{array}$ & $\begin{array}{c}40.3 \\
(14.0) \\
\end{array}$ \\
\hline Male & 0.49 & 0.49 & 0.49 & 0.49 & 0.49 & 0.49 & 0.49 \\
\hline White & 0.81 & 0.83 & 0.81 & 0.81 & 0.80 & 0.73 & 0.84 \\
\hline Black & 0.06 & 0.06 & 0.06 & 0.06 & 0.06 & 0.10 & 0.05 \\
\hline Hispanic & 0.082 & 0.075 & 0.082 & 0.084 & 0.086 & 0.123 & 0.068 \\
\hline Non-citizen & 0.073 & 0.072 & 0.074 & 0.072 & 0.073 & 0.085 & 0.069 \\
\hline Married & 0.494 & 0.501 & 0.492 & 0.497 & 0.485 & 0.5 & 0.492 \\
\hline Military service & 0.065 & 0.069 & 0.066 & 0.065 & 0.058 & 0.059 & 0.067 \\
\hline Child aged 0-5 & 0.04 & 0.04 & 0.041 & 0.04 & 0.039 & 0.041 & 0.04 \\
\hline Child aged 6-17 & 0.099 & 0.1 & 0.099 & 0.099 & 0.097 & 0.106 & 0.096 \\
\hline $\begin{array}{l}\text { Children aged } \\
0-5 \text { and 6-17 }\end{array}$ & 0.029 & 0.029 & 0.029 & 0.029 & 0.029 & 0.032 & 0.028 \\
\hline $\begin{array}{l}\text { Difficulty with } \\
\text { English }\end{array}$ & 0.07 & 0.069 & 0.071 & 0.072 & 0.069 & 0.084 & 0.066 \\
\hline No diploma & 0.117 & 0.12 & 0.119 & 0.118 & 0.111 & 0.123 & 0.115 \\
\hline HS grad/GED & 0.253 & 0.255 & 0.255 & 0.248 & 0.256 & 0.252 & 0.254 \\
\hline Some college & 0.289 & 0.29 & 0.286 & 0.291 & 0.288 & 0.283 & 0.291 \\
\hline College graduate & 0.341 & 0.335 & 0.34 & 0.343 & 0.346 & 0.342 & 0.341 \\
\hline Observations & 347,169 & 85,343 & 85,864 & 88,683 & 87,279 & 83,934 & 263,235 \\
\hline
\end{tabular}




\begin{tabular}{|c|c|c|c|c|}
\hline \multicolumn{5}{|c|}{ Table 2: Employment in Large Firms } \\
\hline $\begin{array}{l}\text { NAICS } \\
\text { Code }\end{array}$ & Industry & $\begin{array}{c}2012 \\
\text { Employment }\end{array}$ & $\begin{array}{l}\text { Fraction } \\
\text { In large } \\
\text { firm }\end{array}$ & $\begin{array}{c}\text { Fraction } \\
\text { Employment } \\
\text { Not } \\
\text { Suppressed } \\
\end{array}$ \\
\hline & Full state & $1,463,732$ & 0.59 & 1.00 \\
\hline 11 & Agriculture, Forestry, Fishing and Hunting & 338 & 0.00 & 0.84 \\
\hline 21 & Mining, Quarrying, and Oil and Gas Extraction & 1,111 & 0.00 & 0.37 \\
\hline 23 & Construction & 49,438 & 0.25 & 0.96 \\
\hline 31 & Manufacturing & 153,757 & 0.69 & 0.79 \\
\hline 42 & Wholesale Trade & 72,424 & 0.56 & 1.00 \\
\hline 44 & Retail Trade & 183,809 & 0.49 & 1.00 \\
\hline 48 & Transportation and Warehousing & 39,996 & 0.68 & 1.00 \\
\hline 51 & Information & 36,542 & 0.65 & 0.94 \\
\hline 52 & Finance and Insurance & 115,456 & 0.55 & 0.72 \\
\hline 53 & Real Estate and Rental and Leasing & 18,753 & 0.18 & 0.84 \\
\hline 54 & Professional, Scientific and Technical Services & 102,622 & 0.53 & 0.96 \\
\hline 55 & Management of Companies and Enterprises & 36,011 & 0.86 & 0.99 \\
\hline 56 & $\begin{array}{l}\text { Administrative and Support and Waste } \\
\text { Management and Remediation Services }\end{array}$ & 90,045 & 0.67 & 0.93 \\
\hline 61 & Educational Services & 66,005 & 0.86 & 1.00 \\
\hline 62 & Health Care and Social Assistance & 268,876 & 0.68 & 1.00 \\
\hline 71 & Arts, Entertainment, and Recreation & 25,460 & 0.50 & 0.97 \\
\hline 72 & Accommodation and Food Services & 134,280 & 0.29 & 0.88 \\
\hline 81 & Other Services, except Public Administration & 59,762 & 0.12 & 0.97 \\
\hline 99 & Unclassified & 55 & 0.00 & 0.84 \\
\hline
\end{tabular}




\begin{tabular}{|c|c|c|c|c|c|c|c|c|c|}
\hline \multirow[b]{2}{*}{$\begin{array}{l}P O S T_{i t} \\
\cdot T_{R E A T}\end{array}$} & \multicolumn{3}{|c|}{ In labor force } & \multicolumn{3}{|c|}{ Unemployed } & \multicolumn{3}{|c|}{ Worked } \\
\hline & $\begin{array}{c}0.0022 \\
(0.0020)\end{array}$ & $\begin{array}{c}0.0022 \\
(0.0026)\end{array}$ & $\begin{array}{c}-0.0061 \\
(0.0116)\end{array}$ & $\begin{array}{c}0.0088 \\
(0.0010)\end{array}$ & $\begin{array}{c}0.0089 \\
(0.0023)\end{array}$ & $\begin{array}{c}0.0023 \\
(0.0025)\end{array}$ & $\begin{array}{c}-0.0092 \\
(0.0016)\end{array}$ & $\begin{array}{c}-0.0092 \\
(0.0016)\end{array}$ & $\begin{array}{l}-0.0124 \\
(0.0017)\end{array}$ \\
\hline$P O S T_{i t}$ & $\begin{array}{l}-0.0053 \\
(0.0023)\end{array}$ & --- & --- & $\begin{array}{c}-0.0063 \\
(0.0022)\end{array}$ & --- & -- & $\begin{array}{c}0.0027 \\
(0.0033)\end{array}$ & --- & --- \\
\hline$T R E A T_{i s}$ & $\begin{array}{c}0.0068 \\
(0.0034)\end{array}$ & --- & --- & $\begin{array}{c}0.0028 \\
(0.0033)\end{array}$ & --- & --- & $\begin{array}{c}0.0075 \\
(0.0038)\end{array}$ & --- & --- \\
\hline Obs. & \multicolumn{3}{|c|}{342,278} & \multicolumn{3}{|c|}{266,824} & \multicolumn{3}{|c|}{340,077} \\
\hline \multicolumn{10}{|c|}{ Under 30 Sub-sample } \\
\hline & \multicolumn{3}{|c|}{ In labor force } & \multicolumn{3}{|c|}{ Unemployed } & \multicolumn{3}{|c|}{ Worked } \\
\hline $\begin{array}{l}\text { POST }_{i t} \\
\cdot \text { TREAT }_{i s}\end{array}$ & $\begin{array}{l}-0.0014 \\
(0.0066)\end{array}$ & $\begin{array}{l}-0.0015 \\
(0.0062)\end{array}$ & $\begin{array}{l}-0.0055 \\
(0.0103)\end{array}$ & $\begin{array}{l}0.0046 \\
(0.0028)\end{array}$ & $\begin{array}{l}0.0047 \\
(0.0033)\end{array}$ & $\begin{array}{l}0.0017 \\
(0.0041)\end{array}$ & $\begin{array}{l}-0.0089 \\
(0.0083)\end{array}$ & $\begin{array}{l}-0.0090 \\
(0.0080)\end{array}$ & $\begin{array}{l}-0.0110 \\
(0.0129)\end{array}$ \\
\hline$P O S T_{i t}$ & $\begin{array}{l}-0.0070 \\
(0.0057) \\
\end{array}$ & --- & --- & $\begin{array}{l}-0.0087 \\
(0.0027) \\
\end{array}$ & --- & --- & $\begin{array}{l}0.0035 \\
(0.0081) \\
\end{array}$ & --- & --- \\
\hline$T R E A T_{i s}$ & $\begin{array}{l}0.0062 \\
(0.0077)\end{array}$ & --- & --- & $\begin{array}{l}0.0030 \\
(0.0043)\end{array}$ & --- & --- & $\begin{array}{l}0.0097 \\
(0.0091)\end{array}$ & --- & --- \\
\hline Obs. & \multicolumn{3}{|c|}{86,713} & \multicolumn{3}{|c|}{59,236} & \multicolumn{3}{|c|}{85,974} \\
\hline \multicolumn{10}{|c|}{$\mathbf{3 0}$ and Over Sub-sample } \\
\hline $\begin{array}{l}P_{P O S T_{i t}} \\
\cdot T_{R E A T_{i s}}\end{array}$ & $\begin{array}{l}0.0021 \\
(0.0022)\end{array}$ & $\begin{array}{l}0.0021 \\
(0.0030)\end{array}$ & $\begin{array}{l}-0.0033 \\
(0.0053)\end{array}$ & $\begin{array}{l}0.0102 \\
(0.0012)\end{array}$ & $\begin{array}{l}0.0103 \\
(0.0025)\end{array}$ & \begin{tabular}{|l|}
0.0027 \\
$(0.0028)$
\end{tabular} & $\begin{array}{l}-0.0106 \\
(0.0021)\end{array}$ & $\begin{array}{l}-0.0107 \\
(0.0031)\end{array}$ & $\begin{array}{l}-0.0099 \\
(0.0036)\end{array}$ \\
\hline$P O S T_{i t}$ & $\begin{array}{l}-0.0030 \\
(0.0021) \\
\end{array}$ & --- & --- & $\begin{array}{l}-0.0057 \\
(0.0023) \\
\end{array}$ & --- & --- & $\begin{array}{l}0.0040 \\
(0.0030)\end{array}$ & --- & --- \\
\hline$T R E A T_{i s}$ & $\begin{array}{l}0.0108 \\
(0.0041)\end{array}$ & --- & --- & $\begin{array}{l}0.0023 \\
(0.0035)\end{array}$ & --- & --- & $\begin{array}{l}0.0107 \\
(0.0034)\end{array}$ & --- & --- \\
\hline Obs. & \multicolumn{3}{|c|}{255,565} & \multicolumn{3}{|c|}{207,588} & \multicolumn{3}{|c|}{254,103} \\
\hline $\begin{array}{l}\text { State } \\
\text { dummies? }\end{array}$ & No & Yes & Yes & No & Yes & Yes & No & Yes & Yes \\
\hline $\begin{array}{l}\text { Year } \\
\text { dummies? }\end{array}$ & No & Yes & Yes & No & Yes & Yes & No & Yes & Yes \\
\hline $\begin{array}{l}\text { State-year } \\
\text { trends? }\end{array}$ & No & No & Yes & No & No & Yes & No & No & Yes \\
\hline
\end{tabular}

\section{Appendix}

\begin{tabular}{|c|l|l|l|l|l|l|l|l|l|}
\hline \multicolumn{9}{|c|}{ Appendix Table 1: Estimates of Connecticut's Sick Leave Law } \\
\hline & \multicolumn{3}{|c|}{ In labor force } & \multicolumn{3}{c|}{ Unemployed } & \multicolumn{3}{c|}{ Worked } \\
\hline POST $i t$ & 0.0022 & 0.0013 & -0.0014 & 0.0085 & 0.0085 & -0.0011 & -0.0090 & -0.0098 & -0.0041 \\
$\cdot$ TREAT $_{\text {is }}$ & $(0.0022)$ & $(0.0015)$ & $(0.0034)$ & $(0.0009)$ & $(0.0023)$ & $(0.0052)$ & $(0.0014)$ & $(0.0013)$ & $(0.0048)$ \\
\hline POST $_{i t}$ & -0.0051 & --- & --- & -0.0028 & --- & -- & 0.0008 & --- & -- \\
& $(0.0032)$ & & & $(0.0024)$ & & & $(0.0036)$ & & \\
\hline
\end{tabular}




\begin{tabular}{|c|c|c|c|c|c|c|c|c|c|}
\hline$T R E A T_{i s}$ & $\begin{array}{l}0.0066 \\
(0.0029)\end{array}$ & --- & --- & $\begin{array}{l}-0.0011 \\
(0.0032)\end{array}$ & --- & --- & $\begin{array}{l}0.0097 \\
(0.0040)\end{array}$ & --- & --- \\
\hline$M I N W A G E_{\text {ist }}$ & $\begin{array}{l}0.0005 \\
(0.0076)\end{array}$ & $\begin{array}{l}0.0254 \\
(0.0070)\end{array}$ & $\begin{array}{l}0.0276 \\
(0.0188)\end{array}$ & $\begin{array}{l}0.0101 \\
(0.0059)\end{array}$ & $\begin{array}{l}0.0097 \\
(0.0137)\end{array}$ & $\begin{array}{l}-0.0201 \\
(0.0169)\end{array}$ & $\begin{array}{l}-0.0055 \\
(0.0090)\end{array}$ & $\begin{array}{l}0.0159 \\
(0.0071)\end{array}$ & $\begin{array}{l}0.0481 \\
(0.0205)\end{array}$ \\
\hline $\begin{array}{l}\text { State } \\
\text { dummies? }\end{array}$ & No & Yes & Yes & No & Yes & Yes & No & Yes & Yes \\
\hline $\begin{array}{l}\text { Year } \\
\text { dummies? }\end{array}$ & No & Yes & Yes & No & Yes & Yes & No & Yes & Yes \\
\hline $\begin{array}{l}\text { State-year } \\
\text { trends? }\end{array}$ & No & No & Yes & No & No & Yes & No & No & Yes \\
\hline Sample size & \multicolumn{3}{|c|}{342,278} & \multicolumn{3}{|c|}{266,824} & \multicolumn{3}{|c|}{340,077} \\
\hline \multicolumn{10}{|c|}{$\begin{array}{l}\text { Notes: All specifications are weighted, and correct for non-nested two-way clustering via method in Cameron, } \\
\text { Gelbach and Miller (JBES, 2011). Sample drawn from 2009-2012 ACS using } 6 \text { New England States. All specifications } \\
\text { include controls for age, gender, education, race/ethnicity, citizenship, marital status, military service, children, } \\
\text { difficulty with English and a constant term. }\end{array}$} \\
\hline
\end{tabular}

Once we include all individual level demographic variables, state and year dummies, state, year trends, AND state-level minimum wage, many of our results become statistically insignificant. This is most likely due to the high degree of collinearity among the state minimum wage levels and the combination of state and year dummies and the state-year trend.

New England states minimum wages between 2009 and 2012 were as follows:

Federal: $\$ 6.55$ in 2009, $\$ 7.25$ thereafter

CT: $\$ 8.00$ in $2009, \$ 8.25$ thereafter

MA: $\$ 8.00$

$\mathrm{NH}: \$ 7.25$

$\mathrm{RI}: \$ 7.40$

VT: \$8.06 in 2009-10, \$8.15 in 2011, \$8.46 in 2012

ME: $\$ 7.25$ in 2009, $\$ 7.50$ thereafter

(Source: http://www.dol.gov/whd/state/stateMinWageHis.htm and http://www.dol.gov/whd/minwage/america.htm)

For $\mathrm{MA}, \mathrm{NH}$, and $\mathrm{RI}$, the state dummies would have tracked minimum wage perfectly (with a slight correction for inflation, which was also stable year to year). For VT, a state, year trend with parameter value around 1.02 would have predicted the minimum wage trajectory very closely. For CT and ME, beyond 2009 , state dummies would have tracked minimum wage perfectly.

Overall, then, it is no surprise the inclusion of state minimum wage creates problems for the regression. 